\title{
Heterogeneous Localization of Protein Kinase C in Rat Brain: Autoradiographic Analysis of Phorbol Ester Receptor Binding
}

\author{
Paul F. Worley, Jay M. Baraban, and Solomon H. Snyder \\ Departments of Neuroscience, Pharmacology and Experimental Therapeutics, Neurology, \\ Psychiatry and Behavioral Sciences, Johns Hopkins University School of Medicine, Baltimore, Maryland 21205
}

Protein kinase $\mathrm{C}$ is a calcium- and phospholipid-stimulated enzyme present in high concentration in the brain. Phorbol esters are potent tumor promoters that bind to specific receptors with high affinity. Several lines of evidence indicate that the phorbol ester receptor is identical to protein kinase $C$. To determine the distribution of protein kinase $C$, we have localized phorbol ester receptors in the rat brain by autoradiography, using $\left[{ }^{3} \mathrm{H}\right]$ phorbol 12,13-dibutyrate $\left.\left({ }^{3} \mathrm{H}\right] \mathrm{PDBu}\right)$ and have performed a variety of lesions to assess the nature of the cellular elements possessing the binding sites. The [ $\left.{ }^{3} \mathrm{H}\right] \mathrm{PDB}$ binding sites in the rat brain are discretely localized and primarily associated with neurons. Evidence is presented for localization to intrinsic neurons of the cortex and hippocampus, terminals of the striatonigral projection, a projection to the molecular layer of the dentate gyrus, and to dendrites of Purkinje cells.

Protein kinase $\mathrm{C}$ is a calcium- and phospholipid-stimulated, phosphorylating enzyme present in high concentrations in the brain (Blumberg et al., 1984; Inoue et al., 1977; Kuo et al., 1980; Takai et al., 1977). Its activity appears to be linked closely to the phosphoinositide (PI) cycle, since diacylglycerol, which is generated by the PI cycle, may be an endogenous activator of protein kinase $C$ (Nishizuka, 1984). Phorbol esters are potent tumor promoters that bind to specific receptor sites with high affinity (Driedger and Blumberg, 1980; Shoyab and Todaro, 1980). Several lines of evidence indicate that the phorbol ester receptor is identical to protein kinase C (Castagna et al., 1982; Kikkawa et al., 1983; Niedel et al., 1983). Accordingly, one can assess the distribution of protein kinase $\mathrm{C}$ by monitoring the binding of the potent phorbol ester receptor ligand $\left[{ }^{3} \mathrm{H}\right]$ phorbol 12,13-dibutyrate ([$\left.\left.{ }^{3} \mathrm{H}\right] \mathrm{PDBu}\right)$. In whole-body autoradiographic studies, we observed the highest density of phorbol ester receptor binding in the central nervous system of young rats (Murphy et al., 1983). In a preliminary autoradiographic study, Nagle and Blumberg (1983) observed regional variations of phorbol ester receptor binding sites in mouse brain. In the present study, we have characterized in detail the localization of phorbol ester receptor binding sites in rat brain and have performed a variety of lesions to assess the nature of the cellular elements possessing the binding sites.

\footnotetext{
Received Mar. 25, 1985; accepted July 11, 1985

This work was supported by USPHS Grants MH-18501, PSA Award AG 00256 to P.F.W., RSA Award DA-00074 to S.H.S., and a grant of the McKnight Foundation. We wish to thank Nancy Bruce, Pamela Douglas, and Dawn Dodson for their help in preparing the manuscript, and Naomi Taylor for expert technical assistance. We also wish to thank David Lynch and Dr. S. Strittmatter for help with lesion studies, and Dr. M. Molliver for valuable discussions. This work was conducted while J.M.B. was a Pfizer Postdoctoral Fellow.

Correspondence should be addressed to Solomon H. Snyder, Department of Neuroscience, Johns Hopkins University School of Medicine, 725 North Wolfe Street, Baltimore, MD 21205.

Copyright @ 1986 Society for Neuroscience $0270-6474 / 86 / 010199-09 \$ 02.00 / 0$
}

\section{Materials and Methods}

\section{['H]PDBu autoradiography of phorbol ester binding sites}

[ $\left.{ }^{3} \mathrm{H}\right] \mathrm{PDBu}$ autoradiography was carried out as described by Murphy et al. (1983), with minor variations. Male Sprague-Dawley rats (200-250 gm) (Hilltop, Scottdale, PA) were anesthetized with pentobarbital and perfused via the left cardiac ventricle with $50 \mathrm{~mm}$ sodium phosphate, pH $7.5 / 100 \mathrm{~mm} \mathrm{NaCl}$, followed by $50 \mathrm{~mm}$ sodium phosphate, $\mathrm{pH} 7.5$ / $0.3 \mathrm{~m}$ sucrose. Brains were removed and frozen in brain paste on microtome chucks. Cryostat sections $(8 \mu \mathrm{m})$ were thaw-mounted on gelatin-coated slides and stored at $-20^{\circ} \mathrm{C}$ until use (within 2 months) Labeling of tissue with $\left[{ }^{3} \mathrm{H}\right] \mathrm{PDBu}$ was performed by incubation of the brain sections for $60 \mathrm{~min}$ at $33^{\circ} \mathrm{C}$ in a solution of $50 \mathrm{~mm}$ Tris- $\mathrm{HCl}, \mathrm{pH}$ $7.7 / 100 \mathrm{~mm} \mathrm{NaCl}, 1 \mathrm{~mm} \mathrm{CaCl} 2$ and $2.5 \mathrm{~nm}\left[{ }^{3} \mathrm{H}\right] \mathrm{PDBu}$ (New England Nuclear, Boston, MA, $13.1 \mathrm{Ci} / \mathrm{mmol})$. Preliminary experiments verified that specific $\left[{ }^{3} \mathrm{H}\right] \mathrm{PDBu}$ binding reaches a plateau under these incubation conditions. Nonspecific labeling was assessed by adding $1 \mu \mathrm{M}$ PDBu to the incubation solution. Following incubation, sections were washed twice in ice cold buffer for $2 \mathrm{~min}$, briefly rinsed in ice cold distilled water, and immediately dried under a stream of cold air. Autoradiograms were generated by exposing LKB ultrofilm to the slides at $4^{\circ} \mathrm{C}$ for $7 \mathrm{~d}$, at which time the film was developed. The autoradiogram was analyzed using a computerized microdensitometer (Loats Associates, Westminister, MD) and optical densites were converted to equivalent disintegrations/min (DPM) per $\mathrm{mg}$ of methacrylate (autoradiographic $\left[{ }^{3} \mathrm{H}\right]$ microscales, Amersham, Chicago, IL), as described by Unnerstall et al. (1982). Anatomic structures were verified by examination of toluidine blue-stained sections using the rat brain atlas of Paxinos and Watson (1982). Regional binding of [ $\left.{ }^{3} \mathrm{H}\right] \mathrm{PDBu}$ was assessed in at least threc animals and is reported in Table 1 on an integer scale from 0 to 5 .

Quantitative autoradiography using tritiated ligands is subject to nonuniform quenching of the beta emission by gray- and white-matter regions. Rainbow et al.'s (1984) quantitative study demonstrated a 30\% reduction of apparent $\left[{ }^{3} \mathrm{H}\right]$ ligand binding in pure white-matter regions. This potential source of error must be considered in quantitative autoradiographic studies. However, the range of specific $\left[{ }^{3} \mathrm{H}\right] \mathrm{PDBu}$ binding in the brain is greater than 150-fold (Table 1) and a $30 \%$ increase in white-matter regions would not change the reported scaled values.

To determine the drug specificity of $\left[{ }^{3} \mathrm{H}\right] \mathrm{PDBu}$ binding sites in autoradiographic experiments, phorbol analogs (L.C. Services Corporation, Woburn, MA) were added to the incubation solution. Analogs known to be pharmacologically active, 12-deoxyphorbol 13-isobutryate (DPB) and phorbol 12-myristate 13-acetate (PMA) were added at $1 \mu \mathrm{M}$ concentration, whereas presumably inactive analogs, $4 \alpha$-phorbol 12,13didecanoate (4 $\alpha$-PDD) and phorbol, were added at $10 \mu \mathrm{M}$ (Driedger and Blumberg, 1980; Shoyab and Todaro, 1980). The effect of these agents on $\left[{ }^{3} \mathrm{H}\right] \mathrm{PDBu}$ binding was assessed from autoradiograms using microdensitometry.

\section{['HJPDBu binding to homogenates}

Homogenates were prepared from fresh rat cerebral cortex by homogenization in $20 \mathrm{vol}$ of ice cold $50 \mathrm{~mm}$ Tris- $\mathrm{HCl}, \mathrm{pH} 7.7 / 100 \mathrm{~mm} \mathrm{NaCl} / 1$ $\mathrm{mM} \mathrm{CaCl}{ }_{2}$, with a Brinkmann polytron. Homogenates were centrifuged at $48,000 \times g$ for $15 \mathrm{~min}$. The supernatants were discarded and the pellets resuspended in the homogenization buffer. Binding assay tubes contained tissue $\left(1 \mathrm{mg}\right.$, wet weight) and $\left.{ }^{3} \mathrm{H}\right] \mathrm{PDBu}(2.5 \mathrm{nM})$ in a final volume of $1 \mathrm{ml}$ with $50 \mathrm{~mm}$ Tris- $\mathrm{HCl}, \mathrm{pH} 7.7 / 100 \mathrm{~mm} \mathrm{NaCl} / 1 \mathrm{~mm}$ 
Table 1. Relative densities of $\left[{ }^{3} \mathrm{H}\right] \mathrm{PDBu}$ labeling

\begin{tabular}{|c|c|c|c|c|c|}
\hline Region & $\begin{array}{l}\text { Relative } \\
\text { density }\end{array}$ & Region & $\begin{array}{l}\text { Relative } \\
\text { density }\end{array}$ & Region & $\begin{array}{l}\text { Relative } \\
\text { density }\end{array}$ \\
\hline Olfactory bulb & & Reuniens nucleus & 3 & Midbrain & \\
\hline Olfactory nerve & 1 & Ventral lateral geniculate & & Superior colliculus & \\
\hline External plexiform layer & 4 & nucleus & 1 & Superficial gray layer & 3 \\
\hline Internal granular layer & 3 & Dorsal lateral geniculate & & Optic nerve layer & 1 \\
\hline Glomerular layer & 2 & nucleus & 3 & Intermediate gray layer & 2 \\
\hline Mitral cell layer & 1 & Medial geniculate nucleus & 3 & Intermediate white layer & 1 \\
\hline Anterior olfactory nucleus & 4 & Anterior pretectal area & 1 & Central gray & 3 \\
\hline Olfactory tubercle & 5 & $\begin{array}{l}\text { Posterior pretectal nucleus } \\
\text { Reticular thalamic nucleus }\end{array}$ & $\begin{array}{l}1 \\
2\end{array}$ & Red nucleus & 0 \\
\hline Amygdala & & $\begin{array}{l}\text { Rhomboid nucleus } \\
\text { Rholicular thalamic nucle }\end{array}$ & $\begin{array}{l}2 \\
3\end{array}$ & Substantia nigra & 4 \\
\hline Lateral nucleus & 4 & Gelatinosus nucleus & 3 & Interpeduncular nucleus & 3 \\
\hline Basolateral nucleus & 4 & Paraventricular nucleus & 2 & Inferior colliculus & \\
\hline Basomedial nucleus & 3 & Parafascicular nucleus & 1 & Dorsomedial & 2 \\
\hline Anterior area & 3 & Ventrolateral nucleus & 3 & Ventrolateral & 1 \\
\hline Central nucleus & 3 & Anterodorsal nucleus & 2 & Ventral tegmental area & \\
\hline Medial nucleus & 3 & Anteroventral nucleus & 3 & of Tsai & 2 \\
\hline Basal ganglia & & Anteromedial & 3 & Pons & \\
\hline Caudate-putamen & 4 & External medullary lamina & 1 & Pontine central gray & 2 \\
\hline Globus pallidus & 2 & $\begin{array}{l}\text { Internal medullary lamina } \\
\text { Zona incerta }\end{array}$ & $\begin{array}{l}1 \\
1\end{array}$ & Pontine nucleus & 2 \\
\hline Accumbens nucleus & 4 & Lona incerta & 1 & Locus coeruleus & 2 \\
\hline Claustrum & 3 & Silia intecunatis & & Parabrachial nucleus & 2 \\
\hline Septal area & & Hypothalamus & & Medulla oblongata & \\
\hline Lateral septal nucleus & 4 & Anterior hypothalamic area & 2 & Nucleus of the solitary tract & 2 \\
\hline Medial septal nucleus & 1 & $\begin{array}{l}\text { Periventricular nucleus } \\
\text { Lateral hypothalamic area }\end{array}$ & $\begin{array}{l}1 \\
2\end{array}$ & Interior olive & 2 \\
\hline Diagonal band & 1 & Dorsomedial nucleus & $\begin{array}{l}2 \\
2\end{array}$ & Nucleus of the spinal & \\
\hline Ventral pallidum & 2 & Ventromedial nucleus & 2 & tract of the trigeminal & \\
\hline Septo-fimbrial nucleus & 3 & Suprachiasmatic nucleus & 2 & nerve & \\
\hline Bed nucleus stria terminalis & 3 & Supraoptic nucleus & 3 & Oral part & 1 \\
\hline Septo hippocampal nucleus & 5 & Paraventicular nucleus & 2 & Caudal part & 4 \\
\hline Hippocampal formation & & Arcuate nucleus & 2 & Spinal tract of the & \\
\hline Hippocampus & & Mammillary nuclcus & 2 & trigeminal nerve & 0 \\
\hline stratum oriens CA1 & 5 & Medial preoptic area & 3 & Gracile nucleus & 1 \\
\hline stratum oriens CA3 & 4 & Lateral preoptic area & 3 & $\begin{array}{l}\text { Gracile nucleus } \\
\text { Granular cell layer of }\end{array}$ & 1 \\
\hline stratum radiatum $\mathrm{CA} 1$ & 5 & Pituitary & & cochlear nuclei & 3 \\
\hline stratum radiatum CA3 & 4 & Anterior lobe & 2 & Spinal cord & \\
\hline Dentate gyrus & & Posterior lobe & 3 & Substantia gelatinosa & \\
\hline Granular cell layer & 2 & Cerebral cortex & & $\begin{array}{l}\text { Substantia gelatinosa } \\
\text { Dorsal horn }\end{array}$ & 4 \\
\hline Molecular layer & 4 & & & $\begin{array}{l}\text { Dorsal horn } \\
\text { Ventral horn }\end{array}$ & 1 \\
\hline Hilus & 4 & Neocortex & & $\begin{array}{l}\text { Ventral horn } \\
\text { White matter }\end{array}$ & 0 \\
\hline Subiculum & 4 & Layer I & 5 & White matter & 0 \\
\hline Habenula & & Layers II-VI & 4 & White-matter tracts & \\
\hline Medial nucleus & 3 & Cingulate cortex & & Corpus callosum & 1 \\
\hline Lateral nucleus & 1 & Anterior & 4 & Cingulum & 1 \\
\hline Pineal & 3 & Posterior & 3 & $\begin{array}{l}\text { Internal capsule } \\
\text { Ventral hippocampal }\end{array}$ & 0 \\
\hline Thalamus & & Entorhinal cortex & 4 & commissure & 1 \\
\hline Ventroposterior nucleus, & & Piriform cortex & 4 & Fornix & 0 \\
\hline lateral and medial & 3 & Cerebellum & & Anterior commissure & 0 \\
\hline Mediodorsal nucleus & 3 & Molecular layer & 4 & Lateral olfactory tract & 0 \\
\hline Laterodorsal nucleus & 3 & Granular layer & 1 & Optic tract & 0 \\
\hline Posterior nuclear group & 3 & Deep cerebellar nuclei & 3 & Superior cerebellar peduncle & 0 \\
\hline Paratenial nucleus & 3 & & & Medial lemniscus & 0 \\
\hline
\end{tabular}


$\mathrm{CaCl}_{2}$. Phorbol analogs (1 $\mu \mathrm{M}$ DPB, $1 \mu \mathrm{M}$ PMA, $10 \mu \mathrm{M} 4 \alpha$-PDD, or 10 $\mu \mathrm{M}$ phorbol) were added for competition studies. After $45 \mathrm{~min}$ at $23^{\circ} \mathrm{C}$, samples were filtered over polyethyleneimine- $(0.5 \%)$ pretreated glass fiber filters (Schleicher and Schuell No. 32) with three $3 \mathrm{ml}$ washes of ice cold $50 \mathrm{~mm}$ Tris- $\mathrm{HCl}, \mathrm{pH} 7.7$. The radioactivity remaining on the filters was determined by liquid scintillation spectrometry after elution with $4 \mathrm{ml}$ of Formula 947 (New England Nuclear). Nonspecific binding was defined as the radioactivity remaining in the presence of $1 \mu \mathrm{M}$ PDBu.

\section{Lesion studies}

To produce selective lesions, use was made of differential neuronal sensitivities to various toxins. Quinolinic acid (Sigma, St. Louis, MO) was used to lesion the frontal cortex ( $200 \mathrm{nmol}$ in $2 \mu$ l saline), hippocampal formation (30-200 $\mathrm{nmol}$ in $2 \mu \mathrm{l}$ saline), and caudate nucleus (200-500 nmol in $2 \mu \mathrm{l}$ saline) (Schwarcz et al., 1983). A cerebellar lesion, sparing the granule cells, was produced with kainic acid (Sigma, $2 \mathrm{nmol}$ in $2 \mu$ l saline), as described by Herndon et al. (1980). Ibotenic acid (Regis, Morton Grove, IL, $100 \mathrm{nmol}$ in $0.5 \mu \mathrm{l}$ ) was selected to lesion the substantia nigra, because this toxin produces highly localized nigral lesions (Coyle and Schwarcz, 1983). A granule cell-specific lesion of the dentate gyrus was produced with local injections of colchicine (Sigma, $3 \mu \mathrm{g}$ in $0.6 \mu \mathrm{l}$ saline) (Goldschmidt and Steward, 1980).

All lesions were produced in adult male Sprague-Dawley rats weighing 200-250 gm. The rats were anesthetized with intraperitoneal chloral hydrate, $400 \mathrm{mg} / \mathrm{kg}$, and placed in a stereotactic frame (Kopf Instruments, Tujunga, $\mathrm{CA}$ ). The toxins were dissolved in $0.9 \% \mathrm{NaCl}$, adjusted to $\mathrm{pH} 7.4$ with $0.1 \mathrm{M} \mathrm{NaOH}$, and administered with a Hamilton microsyringe over $1-2 \mathrm{~min}$. Coordinates were determined using the rat brain atlas of Paxinos and Watson (1982) and were confirmed by dye injection in age-matched controls. Lesioned animals were sacrificed after 4-14 d and brain sections were prepared as described above. The lesions were characterized for extent and selectivity by histologic examination of the brain sections with toluidine blue stain, acetylcholinesterase stain, and Cajal's silver stain (Ralis et al., 1973). Autoradiography was performed as described, and computerized microdensitometry was used to determine the quantitative regional effects of the lesions on $\left[{ }^{3} \mathrm{H}\right] \mathrm{PDBu}$ binding.

Nervous mice (nr/nr) (Jackson Laboratory, Bar Harbor, ME), which postnatally lose $90 \%$ of their cerebellar Purkinje cells (Landis, 1973), were perfused and processed for autoradiography as described above. Phenotypically normal littermates $(+/ \mathrm{nr})$ served as controls.

\section{Results}

\section{Specificity of $\left[^{3} \mathrm{H}\right] P D B$ binding}

To insure that autoradiographic patterns obtained with $\left[{ }^{3} \mathrm{H}\right] \mathrm{PDBu}$ reflect pharmacologically relevant phorbol ester receptor binding sites, we compared the potencies of several phorbol ester derivatives in competing for $\left[{ }^{3} \mathrm{H}\right] \mathrm{PDB}$ binding to brain sections that were mounted on microscope slides with their potencies at binding sites in homogenates (Table 2). The close similarity between the potencies of the various phorbol derivatives in homogenates and sections indicates that $\left[{ }^{3} \mathrm{H}\right] \mathrm{PDBu}$ labels the same sites in both preparations. Thus, the pharmacologically potent phorbol derivatives, DPB and PMA (1 $\mu \mathrm{M})$ (Driedger and Blumberg, 1980; Shoyab and Todaro, 1980), displace nearly all the binding in both sections and homogenates, whereas phorbol and $\alpha 4$-PDD, which have negligible pharmacologic activity,
Table 2. Pharmacology of $\left[{ }^{3} \mathrm{H}\right] \mathrm{PDB} u$ binding in brain sections and homogenates

\begin{tabular}{|c|c|c|c|}
\hline \multirow{2}{*}{$\begin{array}{l}\text { Phorbol } \\
\text { analog }\end{array}$} & \multirow{2}{*}{$\begin{array}{l}\text { Concentration } \\
(\mu \mathrm{M})\end{array}$} & \multicolumn{2}{|c|}{$\begin{array}{l}\% \text { Inhibition of } \\
{ }^{3} \mathrm{H}-\mathrm{PDBu} \text { binding }\end{array}$} \\
\hline & & Homogenate & Slice \\
\hline Phorbol & 10 & $0 \pm 2$ & $3 \pm 3$ \\
\hline $4 \alpha-\mathrm{PDD}$ & 10 & $0 \pm 2$ & $8 \pm 4$ \\
\hline DPB & 1 & $87 \pm 2$ & $83 \pm 5$ \\
\hline PMA & 1 & $105 \pm 2$ & $96 \pm 2$ \\
\hline
\end{tabular}

Comparison of phorbol analogs in inhibiting $\left[{ }^{3} \mathrm{H}\right] \mathrm{PDBu}$ binding to rat cortex homogenate and to brain sections. Homogenate data were determined in triplicate from three rats. Slice data were determined in triplicate for two rats from the autoradiograms, using microdensitometry to assay cortical $\left[{ }^{3} \mathrm{H}\right] \mathrm{PDBu}$ binding. Nonspecific binding was defined as the radioactivity remaining in the presence of $1 \mu \mathrm{M}$ PDBu for both the homogenate and slice binding. Data are mean values with SEM. PDBu, phorbol 12,13-dibutyrate; $4 \alpha$-PDD, $4 \alpha$-phorbol 12,13-didecanoate; PMA, phorbol 12-myristate, 13-acetate; DPB, 12-deoxyphorbol 13-isobutyrate.

are also extremely weak in competing for binding sites in homogenates or sections.

\section{Autoradiographic localization of [ $\left.{ }^{3} \mathrm{H}\right] P D B$ binding}

The distribution of $\left[{ }^{3} \mathrm{H}\right] \mathrm{PDBu}$ binding throughout the brain is strikingly heterogeneous (Table 1 and Fig. 1). Within the olfactory bulb, clear differences in grain density among various layers are evident (Fig. 1 $\mathrm{A}$ ). The olfactory nerve layer and the glomerular layer, which contain the terminals of the olfactory nerves, have relatively low grain density. The highest density in the olfactory bulb appears in the external plexiform layer $(E P$; Fig. $1 A$ ), which contains dendro-dendritic connections between mitral cell and granule cell dendrites. The adjacent mitral cell layer $(M I$; Fig. $1 A$ ) displays a markedly lower grain density compared to either the internal granular layer or the external plexiform layer that surrounds it. The anterior olfactory nucleus $(A O$; Fig. $1 B$ ) has high grain densities, similar to the nearby frontal cerebral cortex (Fig. $1 B$ ). Within the primary olfactory cortex $(P O$; Fig. $1 C$ ) there is substantial $\left[{ }^{3} \mathrm{H}\right] \mathrm{PDB}$ binding to the molecular layer, bordered by a layer of low grain density associated with the perikarya of the pyramidal cells (arrows; Fig. 1C).

In the basal ganglia, very high density occurs in the caudateputamen (Fig. 1, $D-G$ ), with grains largely absent over whitematter bundles. The adjacent globus pallidus possesses substantially lower levels of grains than the caudate-putamen. Within the septal area, there are marked variations in grain density. Extremely high densities are present in the dorsal portion of the lateral septal nucleus ( $S$; Fig. $1 E$ ), whereas the medial septal nucleus has low levels of autoradiographic grains. Relatively low receptor densities also occur in the diagonal band nuclei $(D B ;$ Fig. $1 D)$ and the ventral pallidum ( $V P$; Fig. $1 E)$. Among the amygdala $(A$; Fig. $1 H$ ), grain densities are similar though the lateral nuclei are somewhat higher than the more medial nuclei.

Figure 1. $A-P$, Rat brain autoradiographic mapping of $\left[{ }^{3} \mathrm{H}\right] \mathrm{PDBu}$ binding sites. Representative brain sections are presented in a rostral to caudal progression. White areas correspond to regions with high phorbol ester receptor densities. $A, M I=$ mitral cell layer of olfactory bulb; $E P=$ external plexiform layer; $I G=$ internal granular cell layer. $B, F C=$ frontal cortex; $A O=$ anterior olfactory nucleus; arrows point to cortical rim of enhanced binding. $C, P O=$ primary olfactory cortex; arrows point to pyramidal cell layer of olfactory cortex. $D, D B=$ nucleus of the diagonal band; $O T=$ olfactory tubercle. $E, C P=$ caudate putamen; $G=$ globus pallidus; $V P=$ ventral pallidum; $F=$ fornix; $S=$ lateral dorsal septal nucleus. $F, P V=$ periventricular hypothalamic nucleus; $I M=$ internal medullary velum. $G, H I=$ hippocampal formation; $T H=$ thalamus; arrows point to stratum pyramidale. $H, P=$ posterior cingulate cortex; $A=$ amygdala complex; $I N=$ internal capsule; $D=$ dorsal lateral geniculate nucleus; $V=$ ventral lateral geniculate nucleus; $G D=$ granular cell layer of the dentate gyrus. $I, R=$ red nucleus; $S N=$ substantia nigra. $J, S C=$ superior colliculus. $K$, $P A=$ periaqueductal gray. $L, I C=$ inferior colliculus; $P G=$ pontine gray; $P B=$ parabrachial nuclei. $M, D N=$ deep nuclei of the cerebellum; $I O=$ inferior olivary nucleus; $C=$ granular cell layer of the vestibular nuclei. $N, M L=$ molecular layer of cerebellum; $G L=$ granular cell layer of cerebellum. $O, S T=$ nucleus of the spinal trigeminal tract. $P, S G=$ substantia gelatinosa. See text for methods and further details. 

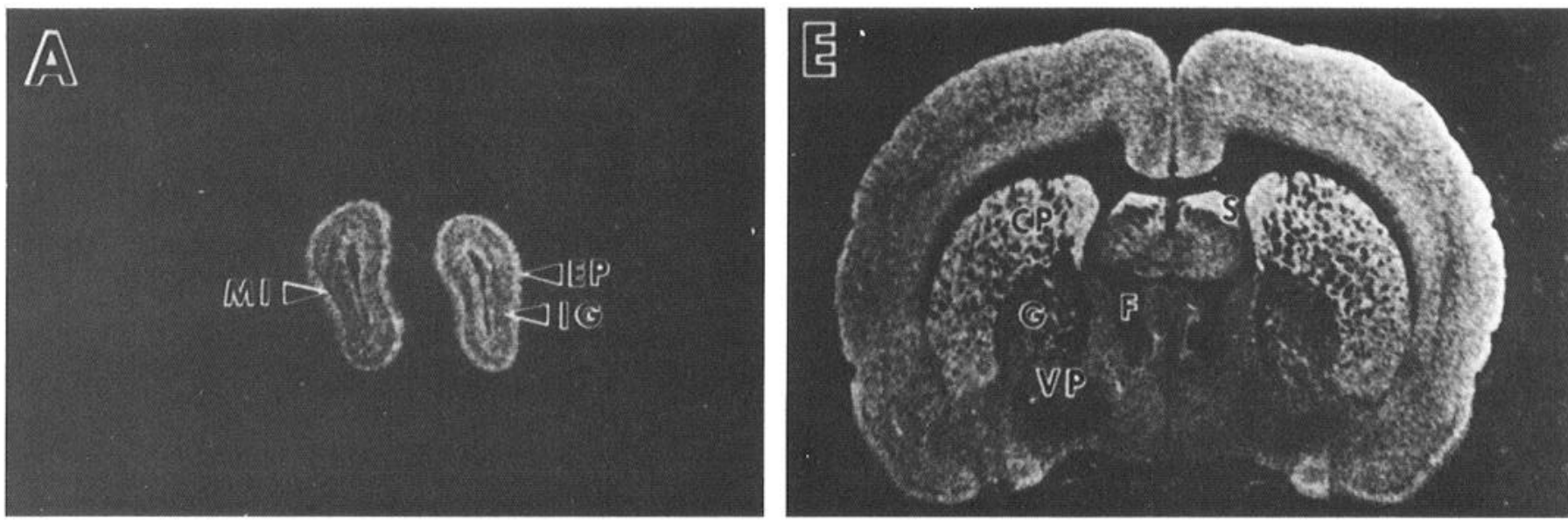

B
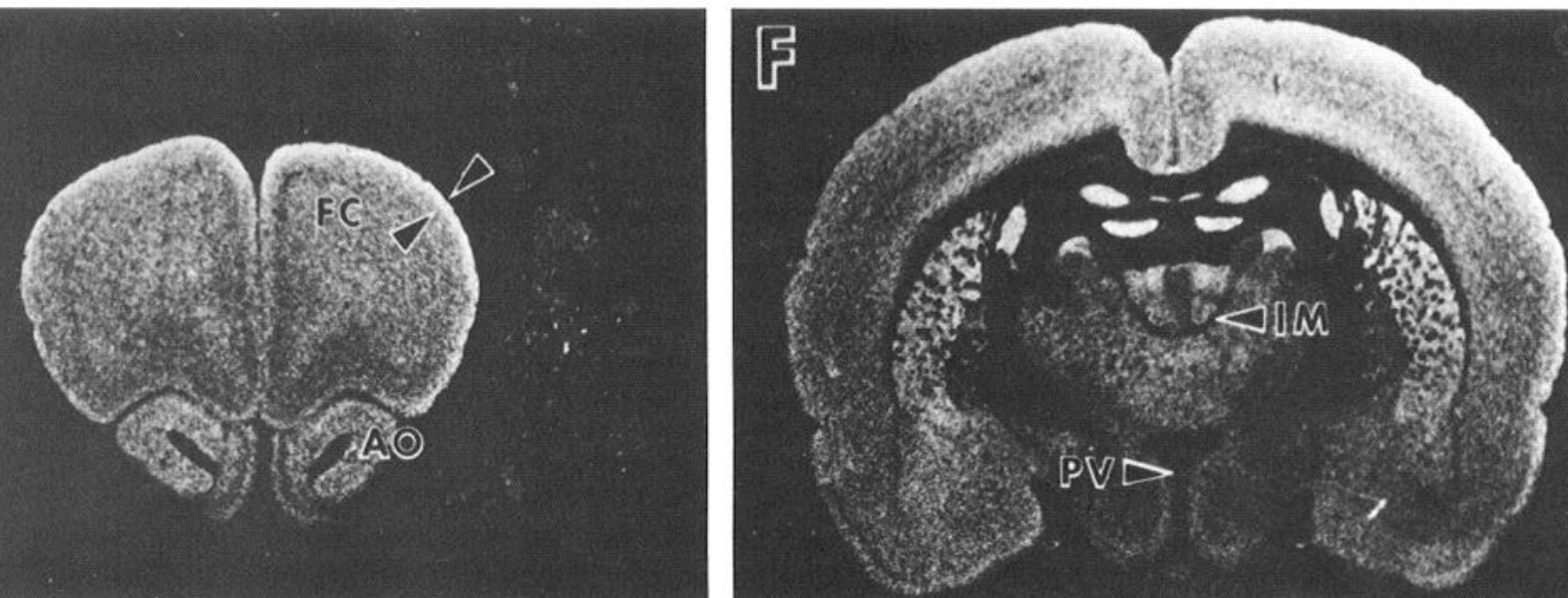

C
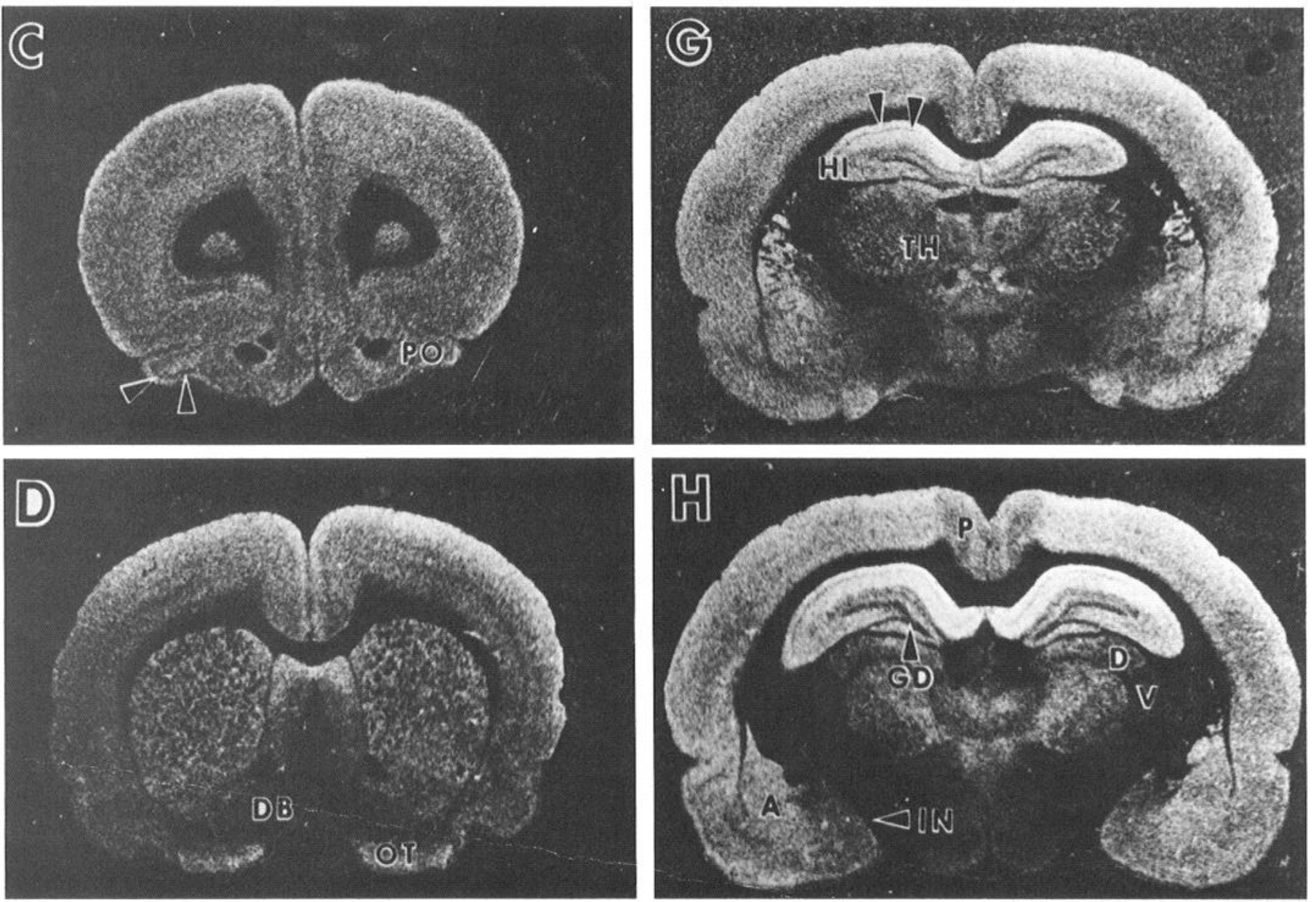

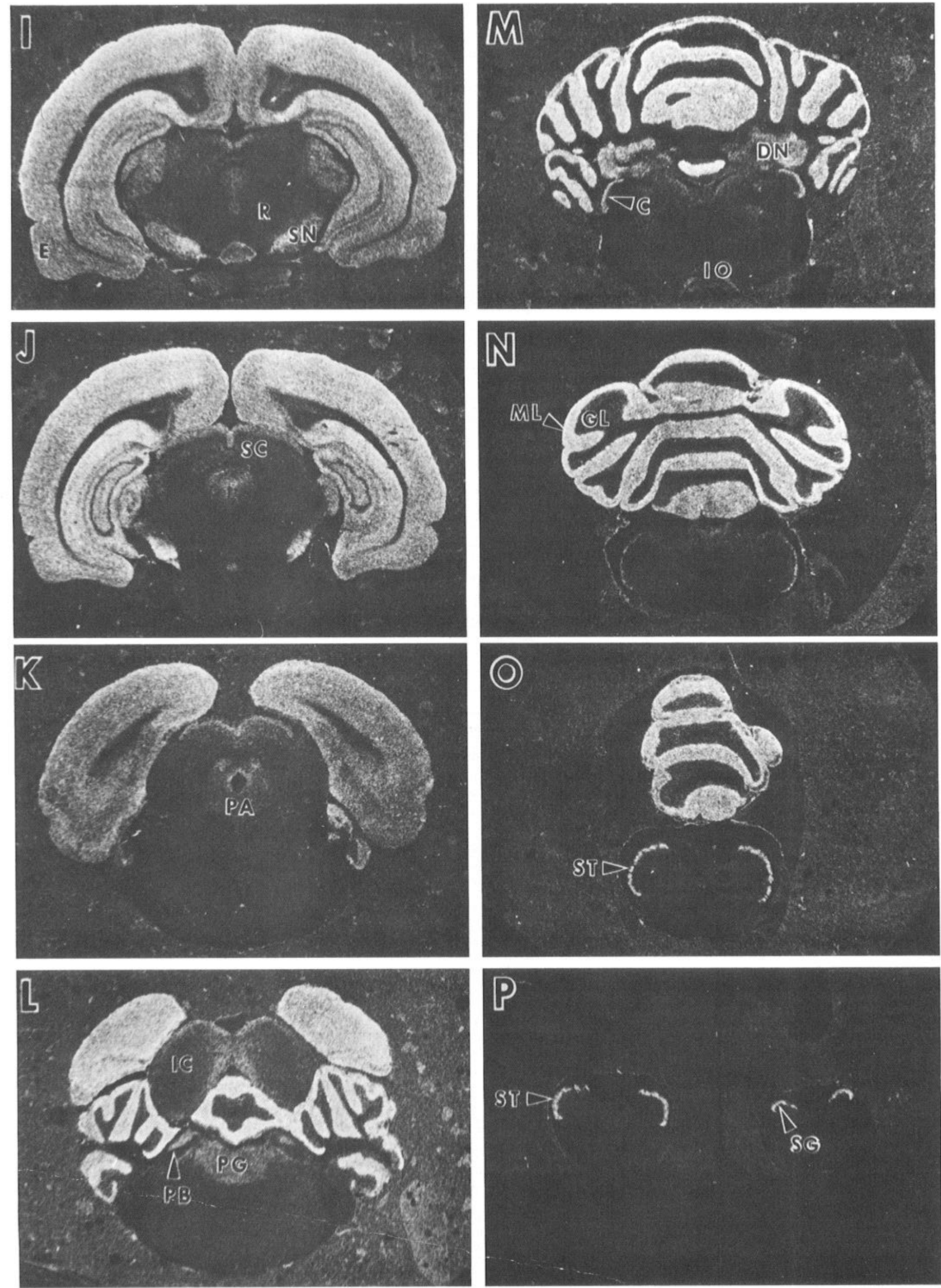

P

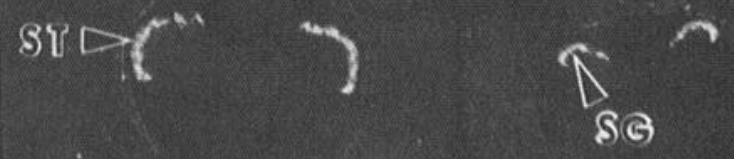



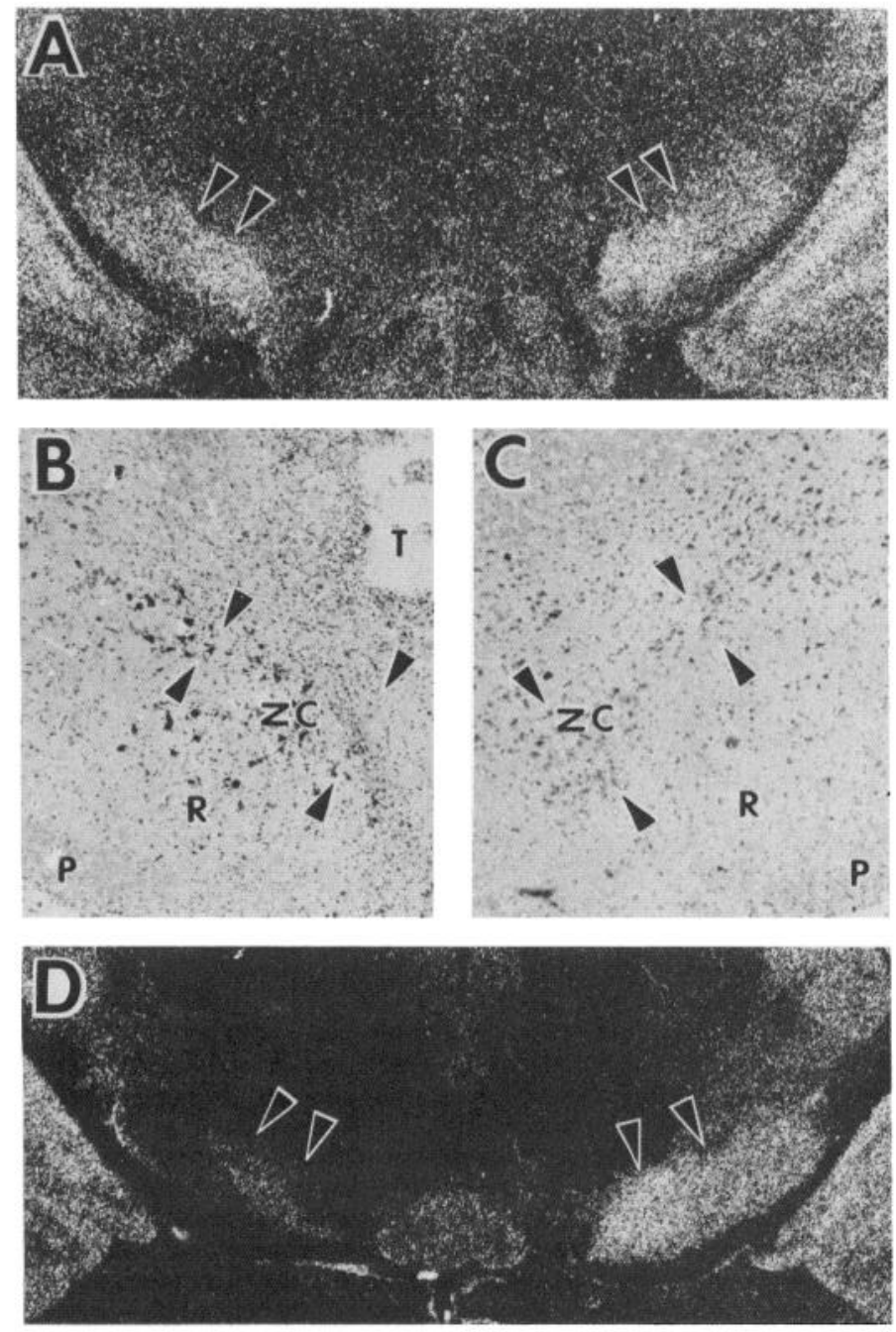

Figure 2. Lesions of the nigrostriatal system: $A$, Autoradiogram of a brain section through the substantia nigra of a rat which had been lesioned on the left side $14 \mathrm{~d}$ previously with $100 \mathrm{nmol}$ of ibotenic acid. Degeneration of the nigral neurons did not affect the density of $\left[{ }^{3} \mathrm{H}\right] \mathrm{PDBu}$ binding sites in the nigra, which remain symmetric (arrows). $B$ and $C$, Micrograph $(40 \times)$ of the brain section shown in $A$ stained with toluidine blue. $B$ demonstrates the loss and pyknotic degeneration of the nigral neurons, $Z C$ and arrows. Also labeled are the zona reticulata, $R$; the cerebral peduncle, $P$; and the lesioning needle tract, $T$. $C$ demonstrates the nonlesioned nigra. $D$, Autoradiogram of the substantia nigra (arrows) from a rat lesioned in the left caudate with $500 \mathrm{nmol}$ of quinolinic acid $4 \mathrm{~d}$ prior to sacrifice. Note the marked decrease in labeling of the substantia nigra on the left side.

The hippocampal formation also demonstrates marked variations in $\left[{ }^{3} \mathrm{H}\right] \mathrm{PDBu}$ binding. The highest grain density within the brain occurs in the stratum oriens and stratum radiatum of CA1. In contrast, very low grain density is detected over the pyramidal cell layer (arrows; Fig. $1 G$ ). Similarly, within the dentate gyrus, the granule cell layer $(G D$; Fig. $1 H$ ) possesses substantially fewer autoradiographic grains than the adjacent neuropil-enriched molecular layer.

As observed for the frontal cortex, other areas of the neocortex possess very high grain densities. By contrast, the posterior cingulate cortex $(P$; Fig. $1 H)$ and entorhinal cortex $(E$; Fig. $1 I)$ show somewhat lower grain densities.

Within the thalamus, one can observe an outlining of the various thalamic nuclei by the receptor-poor white-matter laminae $(I M$; Fig. $1 F)$ that divide the thalamic nuclei from each other. The dorsal lateral geniculate $(D$; Fig. $1 H$ ) possesses sub-
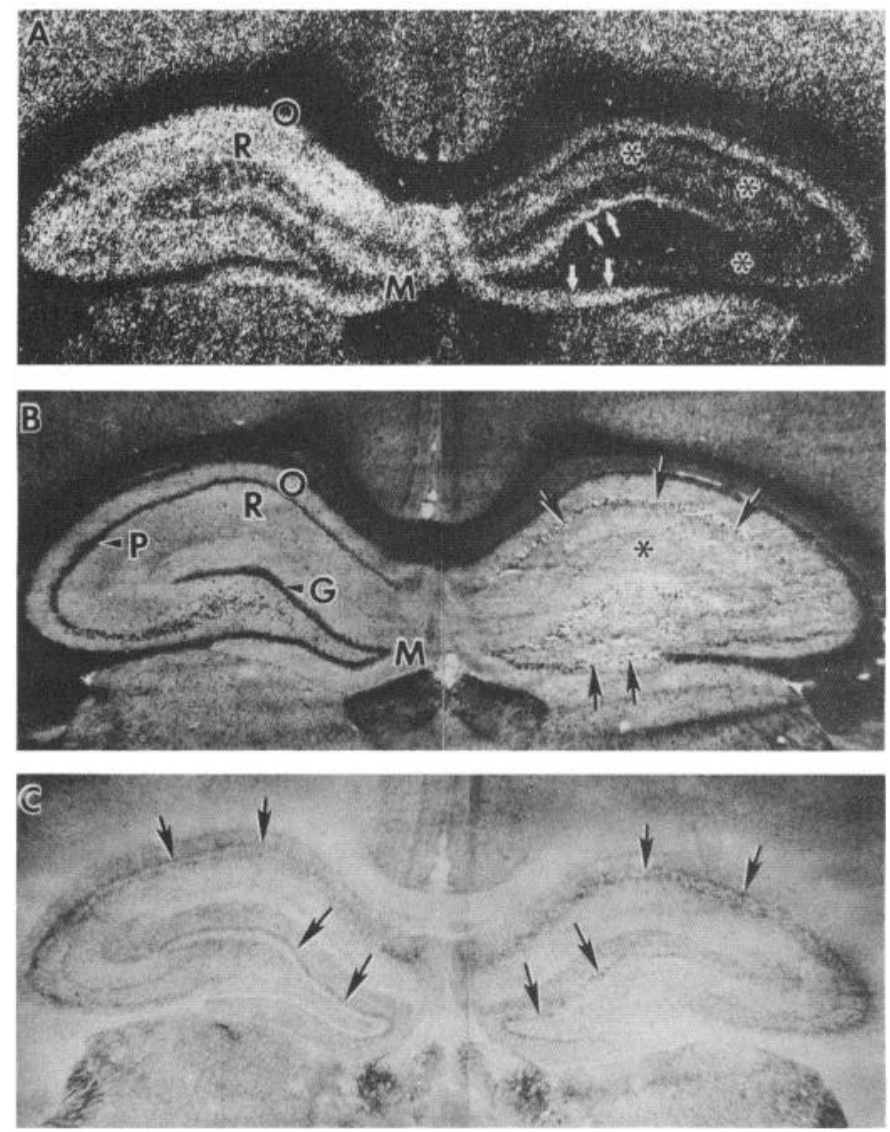

Figure 3. Hippocampal formation lesion. Rat hippocampal formation $4 \mathrm{~d}$ after the unilateral (right) injection of $200 \mathrm{nmol}$ of quinolinic acid. Micrographs are from adjacent sections. Control (nonlesioned) hippocampal formation is on the left. $O=$ stratum oriens; $R=$ stratum radiatum; $P=$ pyramidal cell layer; $G=$ granular cell layer; $M=$ molecular layer of dentate gyrus. $A,\left[{ }^{3} \mathrm{H}\right] \mathrm{PDBu}$ autoradiogram (white areas represent dense binding), demonstrating a marked reduction of silver grains over the strata oriens and radiatum of the entire hippocampus (asterisks) and a preservation of grains over the molecular layer of the dentate gyrus (arrows). B, Toluidine blue stain demonstrating an extensive loss of pyramidal and granular cells in the lesioned hippocampus (arrows) and a preservation of adjacent neuropil (asterisk). C, Acetylcholinesterase stain, demonstrating preservation of the pattern and intensity of cholinesterase activity. Arrows point to the characteristic intense cholinesterase activity in the inner third of the dentate molecular layer and in the narrow bands just above and below the pyramidal cell layer.

stantially higher grain density than the closely adjacent ventral lateral geniculate $(V$; Fig. $1 H)$. Marked variations are apparent in the subdivisions of the hypothalamus. For instance, the periventricular nucleus $(P V$; Fig. $1 F)$ possesses much lower grain density than the immediately adjacent areas of the thalamus and hypothalamus.

Some of the most dramatic variations in grain density occur in the midbrain. For instance, the superficial gray layer of the superior colliculus $(S C$; Fig. $1 J)$ and the periaqueductal central gray $(P A$; Fig. $1 K)$ possess moderate grain densities, which contrast with the few grains in the surrounding tegmentum. The highest grain density within the midbrain occurs in the substantia nigra ( $S N$; Fig. $1 I)$. By contrast, the adjacent red nucleus has virtually no receptors.

Most areas of the pons contain very little receptor binding. The moderate grain density in the pontine gray and the parabrachial nuclei $(P G, P B$; Fig. $1 L)$ contrasts with the surrounding areas that are nearly devoid of grains. The highest density of 
Table 3. Lesion studies

\begin{tabular}{|c|c|c|}
\hline$\underline{\text { Lesioned area }}$ & Region evaluated & $\begin{array}{l}\text { \% Decrease } \\
{\left[{ }^{3} \mathrm{H}\right] \mathrm{PDBu}} \\
\text { binding }\end{array}$ \\
\hline \multirow[t]{2}{*}{ Substantia nigra $(\mathrm{I}, 14 \mathrm{~d})$} & Substantia nigra & $0 \pm 5$ \\
\hline & Corpus striatum & $0 \pm 5$ \\
\hline Corpus striatum $(\mathrm{Q}, 4 \mathrm{~d})$ & Substantia nigra & $65 \pm 12$ \\
\hline \multirow[t]{2}{*}{ Hippocampus $(\mathrm{Q}, 4 \mathrm{~d})$} & $\begin{array}{l}\text { Stratum oriens and stratum } \\
\text { radiatum }\end{array}$ & $60 \pm 5$ \\
\hline & $\begin{array}{l}\text { Molecular layer of dentate } \\
\text { gyrus }\end{array}$ & $0 \pm 10$ \\
\hline Hippocampus (C,8d) & $\begin{array}{l}\text { Molecular layer of dentate } \\
\text { gyrus }\end{array}$ & $0 \pm 10$ \\
\hline Cerebral cortex $(\mathrm{Q}, 4 \mathrm{~d})$ & Cerebral cortex & $50 \pm 10$ \\
\hline Cerebellum $(\mathrm{K}, 4 \mathrm{~d})$ & Molecular layer of cerebellum & m $75 \pm 15$ \\
\hline
\end{tabular}

Lesions were produced in the indicated areas with neurotoxins $(\mathrm{I}=$ ibotenic acid, $\mathrm{Q}=$ quinolinic acid, $\mathrm{C}=$ colchicine, $\mathrm{K}=$ kainic acid), as described in the text, and the animals sacrificed 4-14 d later. The effects of the lesions were evaluated in the ipsilateral region of interest and compared with the contralateral noninjected region. Lesion effects were evaluated in at least three brain sections from each of three animals and quantitated from the autoradiogram. Data are reported as the percentage decrease $( \pm$ SEM $)$ in $\left[{ }^{3} \mathrm{H}\right] \mathrm{PDBu}$ binding due to the lesion.

grains in the pons occurs in the granule layer of the cochlear nuclei $(C$; Fig. $1 M)$.

Low grain densities are also observed in most of the medulla. However, an intense band of receptor binding is apparent in the nucleus of the spinal tract of the trigeminal nerve ( $S T$; Fig. $1, O$ and $P$ ). Also, moderate grain density occurs in the inferior olive $(I O$; Fig. $1 M)$. The spinal cord has very little receptor binding except for a dense band of receptors in the substantia gelatinosa $(S G$; Fig. $1 P)$ which is continuous with the nucleus of the spinal tract of the trigeminal nerve in the lower brain stem.

Some of the highest grain densities in the brain occur in the molecular layer of the cerebellum $(M L$; Fig. $1 N)$, while the adjacent granule cell layer contains a much lower density of binding sites. A moderate level of receptor binding is apparent in the deep nuclei of the cerebellum ( $D N$; Fig. $1 M)$.

Most white-matter tracts throughout the brain either contain very low levels of receptor binding or are totally devoid of activity, as in the fornix $(F ;$ Fig. $1 E)$ and internal capsule (IN; Fig. $1 H)$.

\section{Effect of lesions on [ $\left.{ }^{3} \mathrm{H}\right] P D B u$ binding}

To ascertain the cellular localization of receptor binding sites, we examined the effects of neurotoxin lesions upon grain densities in various areas of the brain (Table 3). Administration of ibotenic acid unilaterally near the substantia nigra produces no loss of $\left.{ }^{3} \mathrm{H}\right] \mathrm{PDBu}$ binding in either the nigra or the caudate despite extensive destruction of nigral neurons (Fig. 2, $A-C$ ). However, unilateral injections of quinolinic acid into the caudate depletes binding of $\left[{ }^{3} \mathrm{H}\right] \mathrm{PDBu}$ markedly in the ipsilateral substantia nigra (Fig. 2D; Table 3 ) as well as in the caudate itself. Accordingly, most phorbol ester receptor binding in the substantia nigra appears to be associated with terminals of the descending striatonigral fibers rather than intrinsic nigral neurons.

Unilateral injections of quinolinic acid into the hippocampus produce a marked loss of grains in both the stratum oriens and stratum radiatum ipsilateral to the injection (Fig. $3 A$; Table 3). By contrast, receptors are unchanged in the ipsilateral molecular layer of the dentate gyrus following the lesion. Histological examination of the lesioned hippocampus shows pronounced loss of both granule cells and pyramidal cells (Fig. 3B). Preservation
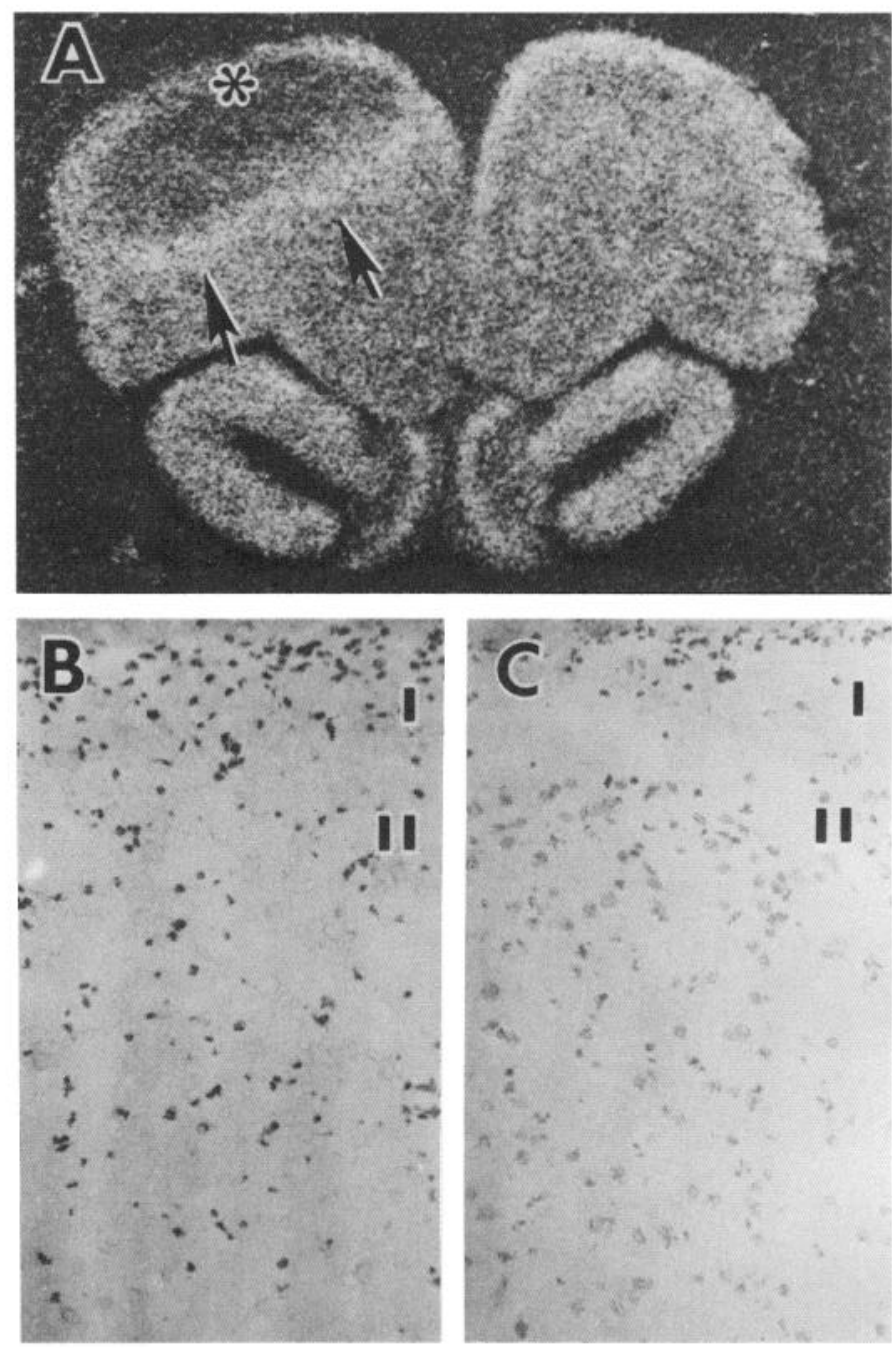

Figure 4. Frontal cortex lesion. Rat frontal cortex $4 \mathrm{~d}$ after unilateral (left) injection of $200 \mathrm{nmol}$ of quinolinic acid. $A,\left[{ }^{3} \mathrm{H}\right] \mathrm{PDBu}$ autoradiogram (white regions represent intense binding), demonstrating a marked reduction of PDBu binding in the lesioned region (asterisk) and a halo of enhanced binding at the periphery of the lesion (arrows). $B$ and $C$, Toluidine blue stain (magnification, $100 \times$ ). Micrograph $(B)$ is from the region marked by the asterisk and $(C)$ is from a comparable area of the control hemisphere. Comparison of $B$ and $C$ demonstrates the loss of neurons from cortical layer II with preservation of the neuropil on the lesioned side.

of acetylcholinesterase staining, a marker for afferent cholinergic terminals (Lewis et al., 1967), indicates that the lesion is selective for intrinsic neurons (Fig. 3C). Thus, the loss of $\left[{ }^{3} \mathrm{H}\right] \mathrm{PDBu}$ binding in the stratum oriens and stratum radiatum reflects phorbol ester receptors associated with intrinsic neurons, while the preserved binding in the molecular layer may be associated with afferent terminals. Further indication that the binding sites in the molecular layer are associated with afferent terminals is provided by selective lesions of the dentate granule cells with colchicine, which also leaves the labeling in the molecular layer unaltered (Table 3).

Quinolinic acid lesions of the neocortex reduce binding uniformly through all layers of the cortex, indicating that phorbol ester receptors are associated with intrinsic neurons (Fig. 4; Table 3). A region of enhanced $\left[{ }^{3} \mathrm{H}\right] \mathrm{PDBu}$ binding is noted frequently near the lesion margin where damaged neurons persist and may represent neuronal response to injury.

Confirming previous reports (Herndon et al., 1980), localized 


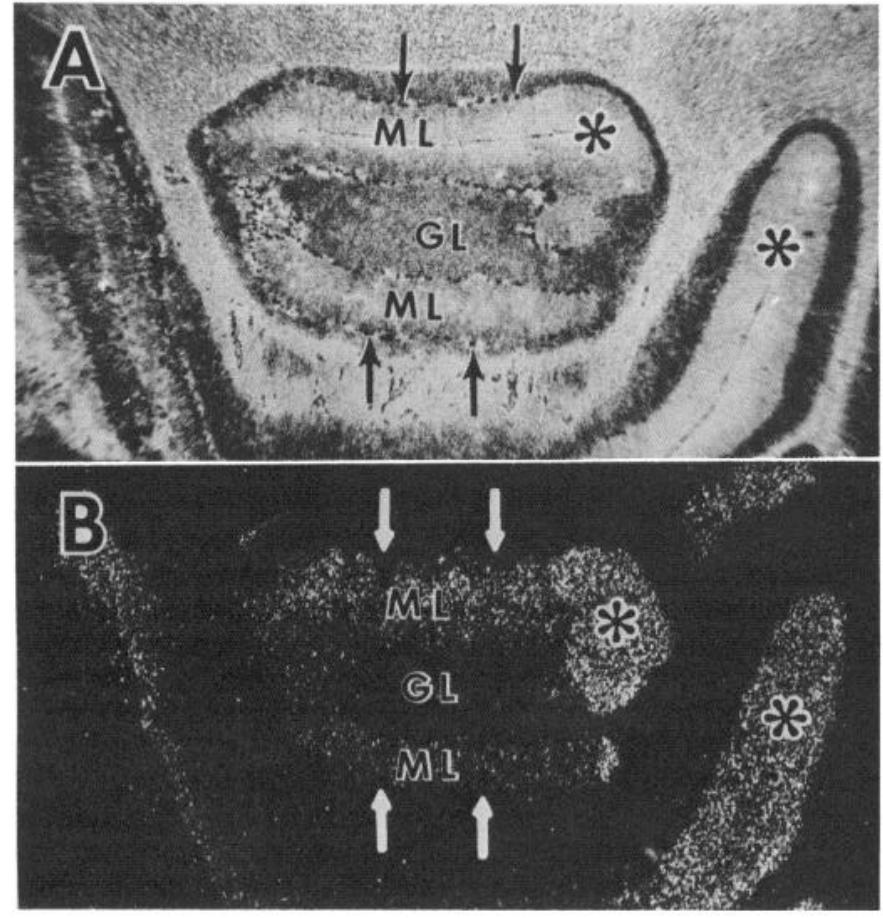

Figure 5. Cerebellar lesion: Rat cerebellar cortex $4 \mathrm{~d}$ following unilateral (left) injection with $2 \mathrm{nmol}$ of kainic acid. Micrographs shown in $A$ and $B$ are from adjacent coronal sections centered on the midline, magnification $25 \times . M L=$ molecular layer; $G L=$ granular cell layer. $A$, Cajal's silver stain demonstrates regions unaffected by toxin (asterisks) and adjacent regions where the Purkinje cells are degenerating (arrows), indicated by dark staining. Unaffected Purkinje cells are inconspicuous at this magnification. The granular cell layer is resistant to the toxin. $B$, $\left[{ }^{3} \mathrm{H}\right] \mathrm{PDBu}$ autoradiogram demonstrates intense labeling over the molecular layer of nonlesioned regions (asterisks) and reduced labeling of the molecular layer coextensive with degenerating Purkinje cells (arrows).

injections of kainic acid into the cerebellum produced regions where Purkinje cells were destroyed with no apparent loss of granule cells (Fig. 5A). In regions of Purkinje cell loss, lower grain density in the molecular layer coincided with Purkinje cell degeneration (Fig. $5 B$; Table 3 ). Since the cerebellum contains several neuronal types that are injured by kainic acid, in addition to the Purkinje cells (Herndon et al., 1980), the reduction in grains might not be attributable only to Purkinje cell loss. We therefore studied the cerebellum of the Nervous mouse, which postnatally loses $90 \%$ of its Purkinje cells (Landis, 1973). As reported by Nagle and Blumberg (1983), the normal mouse cerebellum demonstrates a high density of $\left[{ }^{3} \mathrm{H}\right] \mathrm{PDBu}$ receptors in the molecular layer. $\left[{ }^{3} \mathrm{H}\right] \mathrm{PDBu}$ binding to the molecular layer of the Nervous mouse cerebellum is only $10 \%$ of levels in control littermates (data not shown). Accordingly, a large portion of phorbol ester binding sites in the molecular layer of the cerebellum appears to be associated with dendrites of Purkinje cells.

\section{Discussion}

The major finding of the present study is the markedly heterogeneous distribution of phorbol ester receptor binding in rat brain. A large body of evidence supports the assertion that the phorbol ester receptor is identical to protein kinase C (Castagna et al., 1982; Kikkawa et al., 1983; Niedel et al., 1983). Accordingly, $\left[{ }^{3} \mathrm{H}\right] \mathrm{PDBu}$ mapping presumably reflects the regional distribution of protein kinase $\mathrm{C}$. The autoradiographically observed variations in binding are in general agreement with the regional distribution of protein kinase $\mathrm{C}$ activity measured biochemically (Walaas et al., 1983) and with the regional phorbol ester receptor binding measured in bovine brain homogenates (Nagle et al., 1981). The autoradiographic distribution we observed resembles that reported in the preliminary study by Nagle and Blumberg (1983) in mouse brain.

The lesion experiments indicate that receptor binding is primarily associated with neurons. The high density of binding in neuropil-enriched areas suggests that binding sites are preferentially associated with dendrites and terminals rather than cell bodies. Direct evidence for a localization of receptors to terminals of specific pathways comes from the ipsilateral loss of nigral binding following striatal lesions and is also supported by the preserved binding in the molecular layer of the dentate gyrus following lesions of the hippocampal granule cells. Evidence for localization to dendrites was obtained from cerebellar lesion studies, which indicate that binding in the molecular layer of the cerebellum is largely present on Purkinje cell dendrites. Nonetheless, there may well be receptor binding associated with non-neuronal systems. The limited but definite grain densities observed in the corpus callosum may reflect protein kinase $\mathrm{C}$ associated with the basic protein of brain myelin which is a substrate for this enzyme (Turner et al., 1982).

How might the localization of protein kinase $\mathrm{C}$ relate to neuronal function? Phorbol esters influence hormonal release in a variety of peripheral systems (Koenig et al., 1984; Kojima et al., 1983) and enhance transmitter release from adrenal medullary cells (Knight and Baker, 1983; Pozzan et al., 1984). These findings suggest that protein kinase $\mathrm{C}$ may also regulate neurotransmitter release in the central nervous system, which could account for the association of $\left[{ }^{3} \mathrm{H}\right] \mathrm{PDBu}$ binding with nerve terminals of certain pathways.

Direct evidence for a link between phorbol esters, protein kinase $\mathrm{C}$, and neurotransmission has been obtained recently from physiological studies. In smooth muscle preparations, phorbol esters modulate neurotransmitter-induced contractions (Baraban et al., 1985a). Furthermore, phorbol esters selectively block a calcium-activated potassium conductance in hippocampal pyramidal neurons (Baraban et al., 1985b), an effect also produced by muscarinic agonists (Cole and Nicoll, 1984). Muscarinic agents act post-synaptically to stimulate the PI cycle in the hippocampus (Fisher et al., 1980; Janowsky et al., 1984). The diacylglycerol generated by the PI cycle may activate protein kinase C, as proposed by Nishizuka (1984), and in this way protein kinase $\mathrm{C}$ may mediate some of the effects of the PIlinked neurotransmitters. The map of protein kinase $\mathrm{C}$ localization might then provide an indication of the relative density of neurotransmitter systems that act via the PI cycle. However, several neurotransmitters stimulate the PI cycle, e.g., acetylcholine, serotonin, vasopressin, and substance P (Nishizuka, 1984), making it difficult to correlate the map of phorbol ester binding with a single neurotransmitter candidate.

The distribution of protein kinase $\mathrm{C}$ would be expected to parallel its substrates. A protein designated $\mathrm{F} 1$ is phosphorylated specifically by protein kinase C (Nelson and Routtenberg, 1985) and appears to be identical to the brain-specific protein B-50 which has been mapped immunohistochemically (Oestreicher et al., 1981). In the hippocampus and cerebellum, localizations of protein kinase $\mathrm{C}$ and protein B-50 are quite similar.

Since protein kinase $C$ is stimulated by calcium, it is also of interest to compare its distribution to that of other components of the calcium second-messenger system. $\left[{ }^{3} \mathrm{H}\right] \mathrm{Nitrendipine}$ and $\left[{ }^{3} \mathrm{H}\right] \mathrm{PY}-108-068$ have been used to map the binding sites of calcium channel antagonists which are linked to voltage-dependent calcium channels (Cortes et al., 1984; Gould et al., 1985; Murphy et al., 1982). A number of similarities to the distribution of protein kinase C are apparent. For instance, the external plexiform layer of the olfactory bulb, superficial cerebral cortex, and hippocampal formation are some of the most enriched areas for both calcium antagonist binding sites and protein kinase C. There are also prominent differences, as calcium antagonist 
binding sites in the molecular layer of the dentate gyrus appear to be associated with granule cells (Cortes et al., 1983) rather than with terminals, as was found for protein kinase C. Recently, calcium-calmodulin-dependent protein kinase II has been mapped in rat brain (Ouimet et al., 1984). Its distribution differs considerably from that of protein kinase C. For instance, whereas protein kinase $C$ is enriched in the neuropil portions of the hippocampus with negligible levels in cell layers, the reverse pattern occurs for this calcium-calmodulin-dependent kinase. The complementary distribution of these calcium-dependent protein kinases may provide a clue to their distinctive roles in neuronal calcium signaling.

\section{References}

Baraban, J. M., R. J. Gould, S. J. Peroutka, and S. H. Snyder (1985a) Phorbol ester effects on neurotransmission: Interaction with neurotransmitters and calcium in smooth muscle. Proc. Natl. Acad. Sci. USA 82: 604-607.

Baraban, J. M., S. H. Snyder, and B. E. Alger (1985b) Protein kinase $\mathrm{C}$ regulates ionic conductance in hippocampal pyramidal neurons: Elcctrophysiological effects of phorbol esters. Proc. Natl. Acad. Sci. USA 82: 2538-2542.

Blumberg, P. M., S. Jaken, B. Konig, N. A. Sharkey, K. L. Leach, A. Y. Jeng, and E. Yeh (1984) Mechanism of action of the phorbol ester tumor promoters: Specific receptors for lipophilic ligands. Biochem. Pharmacol. 33: 933-940.

Castagna, M., Y. Takai, K. Kaibuchi, K. Sano, U. Kikkawa, and Y. Nishizuka (1982) Direct activation of calcium-activated, phospholipid-dependent protein kinase by tumor promoting phorbol esters. J. Biol. Chem. 257: 7847-7851.

Cole, A. E., and R. A. Nicoll (1984) The pharmacology of cholinergic excitatory responses in hippocampal pyramidal cells. Brain Res. 305: 283-290.

Cortes, R., P. Supavilai, M. Karobath, and J. M. Palacios (1983) The effects of lesions in the rat hippocampus suggest the association of calcium channel binding sites with specific neuronal populations. Neurosci. Lett. 42: 249-254.

Cortes, R., P. Supavilai, M. Karobath, and J. M. Palacios (1984) Calcium antagonist binding sites in rat brain: Quantitative autoradiographic mapping using the 14-dihydropyridines $\left[{ }^{3} \mathrm{H}\right] \mathrm{PN} 200-110$ and [ ${ }^{3}$ H]PY 108-068. J. Neural Transmitt. 60: 169-197.

Coyle, J. T., and R. Schwarcz (1983) The use of excitatory amino acids as selective neurotoxins. In Handbook of Chemical Neuroanatomy, A. Bjorklund and T. Hokfelt, eds., Vol. 1: Methods in Chemical Neuroanatomy, pp. 508-527, Elsevier, New York.

Driedger, P. E., and P. M. Blumberg (1980) Specific binding of phorbol ester tumor promoters. Proc. Natl. Acad. Sci. USA 77: 564-571.

Fisher, S. K., C. A. Boast, and B. W. Agranoff (1980) The muscarinic stimulation of phospholipid labeling in hippocampus is independent of its cholinergic input. Brain Res. 189: 284-288.

Goldschmidt, R. B., and O. Steward (1980) Preferential neurotoxicity of colchicine for granule cells of the dentate gyrus of the adult rat. Proc. Natl. Acad. Sci. USA 77: 3047-3051.

Gould, R. J., K. M. M. Murphy, and S. H. Snyder (1985) Autoradiographic localization of calcium channel antagonist receptors in rat brain with $\left[{ }^{3} \mathrm{H}\right]$ nitrendipine. Brain Res. 330: 217-223.

Herndon, R. M., J. T. Coyle, and E. Addicks (1980) Ultrastructural analysis of kainic acid lesion to cerebellar cortex. Neuroscience 5: 1015-1026.

Inoue, M., Y. Kishimoto, Y. Takai, and Y. Nishizuka (1977) Studies on a cyclic nucleotide-independent protein kinase and its proenzyme in mammalian tissues. J. Biol. Chem. 252: 7610-7616.

Janowsky, A., L. Rodrigo, and S. M. Paul (1984) Characterization of neurotransmitter receptor-mediated phosphatidylinositol hydrolysis. in rat hippocampus. Life Sci. 35: 1953-1961.

Kikkawa, U., Y. Takai, Y. Tanaka, R. Miyake, and Y. Nishizuka (1983) Protein kinase $\mathrm{C}$ as a possible receptor protein of tumor-promoting phorbol esters. J. Biol. Chem. 258: 11,442-11,445.

Knight, D. E., and P. F. Baker (1983) The phorbol ester TPA increases the affinity of exocytosis for calcium in "leaky" adrenal medullary cells. FEBS Lett. 160: 98-100.

Koenig, R. J., D. Senator, and P. R. Larsen (1984) Phorbol esters as probes of the regulation of thyrotropin secretion. Biochem. Biophys. Res. Commun. 125: 353-359.
Kojima, I., H. Lippes, K. Kojima, and H. Rasmussen (1983) Aldosterone secretion: Effect of phorbol ester and A23187. Biochem. Biophys. Res. Commun. 116: 555-562.

Kuo, J. F., R. G. G. Andersson, B. C. Wise, L. Mackerlova, I. Salomansson, N. L. Brockett, N. Katoh, M. Shoji, and R. W. Wrenn (1980) Calcium-dependent protein kinase: Widespread occurrence in various tissues and phyla of the animal kingdom and comparison of effects of phospholipid, calmodulin and trifluoperazine. Proc. Natl. Acad. Sci. USA 77: 7039-7043.

Landis, S. C. (1973) Ultrastructural changes in the mitochondria of cerebellar Purkinje cells of Nervous mutant mice. J. Cell Biol. 57: 782-797.

Lewis, P. R., C. C. D. Shute, and A. Silver (1967) Confirmation from choline acetylase analysis of a massive cholinergic innervation to the rat hippocampus. J. Physiol. (Lond.) 191: 215-224.

Murphy, K. M. M., R. J. Gould, M. L. Oster-Granite, J. D. Gearhart, and S. H. Snyder (1983) Phorbol ester receptors: Autoradiographic identification in the developing rat. Science 222: 1036-1038.

Murphy, K. M. M., R. J. Gould, and S. H. Snyder (1982) Autoradiographic visualization of $\left[{ }^{3} \mathrm{H}\right]$ nitrendipine binding sites in rat brain: Localization to synaptic zones. Eur. J. Pharmacol. 81: 517-519.

Nagle, D. S., and P. M. Blumberg (1983) Regional localization by light microscopic autoradiography of receptors in mouse brain for phorbol ester tumor promoters. Cancer Lett. 18: 35-40.

Nagle, D. S., S. Jaken, M. Castagna, and P. M. Blumberg (1981) Variation with embryonic development and regional localization of specific $\left[{ }^{3} \mathrm{H}\right]$ phorbol 12,13-dibutyrate binding to brain. Cancer Res. 41 : 89-93.

Nelson, R. B., and A. Routtenberg (1985) Characterization of protein F1 (47 KD, $4.5 \mathrm{pI})$ : A kinase C substrate directly related to neural plasticity. Exp. Neurol. 89: 213-224.

Niedel, J. E., L. J. Kuhn, and G. R. Vanderbark (1983) Phorbol diester receptor copurifies with protein kinase C. Proc. Natl. Acad. Sci. USA 80: $36-40$.

Nishizuka, Y. (1984) Turnover of inositol phospholipids and signal transduction. Science 225: 1365-1370.

Oestreicher, A. B., H. Zwiers, P. Schotman, and W. H. Gispen (1981) Immunohistochemical localization of a phosphoprotein (B-50) isolated from rat brain synaptosomal plasma membranes. Brain Res. Bull. 6: 145-153.

Ouimet, C. C., T. L. McGuinness, and P. Greengard (1984) Immunocytochemical localization of calcium/calmodulin-dependent protein kinase II in rat brain. Proc. Natl. Acad. Sci. USA 81: 5604-5608.

Paxinos, G., and C. Watson (1982) The rat brain in stereotaxic coordinates. Academic, Sydney.

Pozzan, T., G. Gatti, N. Dozio, L. M. Vientine, and J. Meldolesi (1984) $\mathrm{Ca}^{2+}$-dependent and independent release of neurotransmitters from PC1 2 cells: A role for protein kinase C activation? J. Cell Biol. 99: 628-638.

Rainbow, T. C., A. Biegon, and D. J. Berek (1984) Quantitative receptor autoradiography with tritium-labeled ligands: Comparison of biochemical and densitometric measurements. J. Neurosci. Sci. Methods 11: 231-241.

Ralis, H. M., R. A. Beesley, and Z. A. Ralis (1973) Techniques in Neurohistology, Butterworths, London.

Schwarcz, R., W. D. Whetsell, Jr., and R. M. Mangano (1983) Quinolinic acid: An endogenous metabolite that produces axon-sparing lesions in rat brain. Science 219: 316-318.

Shoyab, M., and G. J. Todaro (1980) Specific high affinity cell membrane receptors for biologically active phorbol and ingenol esters. Nature 288: 451-455.

Takai, Y., A. Kishimoto, M. Inoue, and Y. Nishizuka (1977) Studies on a cyclic nucleotide-independent protein kinase and its proenzyme in mammalian tissues. J. Biol. Chem. 252: 7603-7609.

Turner, R. S., C. H. J. Chon, R. F. Kibler, and J. F. Kuo (1982) Basic protein in brain myelin is phosphorylated by endogenous phospholipid-sensitive calcium-dependent protein kinase. J. Neurochem. 39: 1397-1404.

Unnerstall, J. R., D. L. Niehoff, M. J. Kuhar, and J. M. Palacios (1982) Quantitative receptor autoradiography using $\left[{ }^{3} \mathrm{H}\right]$ ultrofilm: Application to multiple benzodiazepine receptors. J. Neurosci. Methods 6 : 59-73.

Walaas, S. I., A. C. Nair, and P. Greengard (1983) Regional distribution of calcium- and cyclic adenosine $3^{\prime}: 5^{\prime}$-monophosphate-regulated protein phosphorylation systems in mammalian brain. II. Soluble systems. I. Neurosci. 3: 302-311. 